\title{
EXECUTIVE COMPENSATION AND FINANCIAL REPORTING QUALITY OF NIGERIAN FINANCIAL SERVICE INDUSTRY
}

\author{
Adeoye Ebunoluwa T. \\ Department of Accounting, Adeleke University, Ede, Osun State, Nigeria \\ E-mail: ebunoluwa.adeoye@adelekeuniversity.edu.ng \\ Akinkoye Ebenezer O. \\ Department of Management and Accounting \\ Obafemi Awolowo University, Ile-Ife, Osun State, Nigeria \\ E-mail: eykoye@yahoo.co.uk \\ Ayoola Tajudeen \\ Department of Management and Accounting \\ Obafemi Awolowo University, Ile-Ife, Osun State, Nigeria \\ E-mail: alabiayoolaaca@yahoo.com \\ Inneh Godwin \\ Department of Management and Accounting \\ Obafemi Awolowo University, Ile-Ife, Osun State, Nigeria \\ Agelebe Glory I. \\ Department of Business Administration \\ Adeleke University, Ede, Osun State, Nigeria
}

\begin{abstract}
The study evaluated the effect of executive compensation on financial reporting quality in Nigerian financial service industry for the period covered. These were with a view to providing information on the effect of executive compensation and financial reporting quality in Nigeria. The study employed a secondary source of data collection. The population for the study consisted of 22 quoted deposit money banks listed and whose stocks are actively traded on the Nigerian Stock Exchange (NSE) market for the period 2006-2017.The sample size of 14 was determined using purposive sampling method. Secondary data were collected on variables executive compensation, non-performing loan, loan loss provision, total loan, residual term all obtained from the audited Annual reports of the selected deposit money banks, fact book published by Nigerian Stock Exchange, and the Central Bank of Nigeria. Data collected were analyzed using Robust Regression. The results showed executive compensation (coef. $=-0.139, p<0.004$ ) has a negative significant relationship with financial reporting quality. This study concluded that executive compensation has a negative significant effect on financial reporting quality.
\end{abstract}

Keywords: Executive Compensation, Financial Reporting Quality. 


\section{INTRODUCTION}

Financial reporting is one of the most significant aspects of an accounting system which aims to provide users with the necessary information to make economic decisions on the evaluation of the viability and quality of an economic enterprise (Mohammadi, 2014). The reliability of financial reporting requires the accuracy of the information published to better describe the activities of a company. High-quality financial reporting is therefore expected to reduce unnecessary or waste of resources. Financial reporting fraud and other forms of wrongdoing in financial reporting are a significant threat to capital markets ' life and performance. This misconduct undermines the trust among firms, investors and market participants required to engage in trade. It also contradicts the key role of resource allocation on the capital markets. This is because the low quality of financial reporting could include manipulating financial statements (Amiram et al., 2018).

Financial reporting is the basis for various stakeholders to take economic decisions and the financial reports produced by the accountant must rely on certain basic criteria for particular stakeholders in order to understand the quality of the document. A substantial body of research indicates that poor financial reporting quality is correlated with a number of negative impacts which are detrimental to an organization's life. These include loss of future revenue, decreases in stock prices, rises in capital costs, and the loss of reputation and confidence, perhaps most significant (Ogbonna \& Ebimobowei, 2012).

The part of corporate governance in financial reporting quality cannot be overemphasized due to the significant role it plays. It is important that executives reflect on decent and effective governance when considering broader board processes, disproportionate executive compensation, audit committee and a minimum board committee size in order to enhance the financial performance of companies (Darweesh, 2015). The global financial crisis claimed to have been caused in part by bank executives ' excessive risk-taking, has heightened questions about the compensation paid to banks' executives (Omoregie \& Kelikume, 2017). The banking sector in Nigeria has undergone financial distress, which has led to the winding up of several financial service industry to date. Failure to comply with regulatory proper codes and excessive compensation will affect the quality of financial statements (Adegbie \& Fofah, 2016).

Amid the financial reporting scandals of the late 1990s and the late 2000s recession crisis, some questioned the salaries of executives and the benefits provided by such compensation packages (Devers, Cannella, Reilly, \& Yoder, 2007; Bebchuk, Grinstein, \& Peyer, 2010). Although equity-based and productivity-based compensation can reduce aversion of work, this compensation often enables executives to exploit accounting figures to increase their remuneration, thereby affecting the quality of the financial reports. Executive compensation is usually been used by the directors to enrich their pockets to the detriments of the stakeholders and shareholders. The kind of compensation in organizations determine the actions and reactions of directors. The directors usually manipulate their compensation so as to favor the executives. For instance, if their compensation is tied to stocks, the directors will do anything to make the price of stock price to appreciate so as to improve or have a higher compensation for themselves. If the executive compensation is performance tied it means that the directors will influence the financial statements so as to boost their compensation. Executive compensation can be influenced by several factors some of which have been identified by literature to be return on investment, return on equity, return on income and the profitability, size of a firm.

The executive compensation program is one of the management team's important ways of directing and shaping behaviour. Executive pay is a major problem in both corporate and realistic discourse as the systemic style is uncertain (Otten, 2008). Though, executive compensation is 
viewed as an important link between top executives and financial reporting quality (Akewushola \& Saka, 2018).

Stakeholders depend on financial reporting performance and accountability and rely on the bank to fulfill its task of fostering financial well-being and permanency. Damage of public assurance in the financial sector could cause serious problems of public and economic benefit. Nonetheless, it is not easy to detect real unscrupulous financial reporting as decisions on unethical financial reporting are consolidated within financial reports (Carpenter \& Reimers, 2005). The need for the study of executive compensation in organizations is associated with the fact that an organizational strategic plan is the primary responsibility of the executives and they take strategic decisions on issues affecting the entire firm. However, some studies showed mixed reactions to the study of executive compensation and financial reporting quality. Executive compensation and financial reporting quality need to be studied in order to maximize shareholders' wealth. Although much has been written on corporate governance and financial reporting quality Nerantzidis (2018); Zadeh, Salehi, and Shabestari (2018); Yiu, Wan, and Xu (2019); Kalyani, Mathur, and Gupta (2019); Akgun (2016); Hong, Li, and Minor (2016); Oba (2014); Habib and Jiang (2014); Dimitrova et al. (2016); Goodwin and Seow (2002), few studies exist on the mechanism of executive compensation on the financial reporting quality in Nigeria.

\section{Executive Compensation}

\section{LITERATURE REVIEW}

The term executive compensation refers to the financial payments and non-financial monetary benefits given to high-level management in exchange for their work on behalf of an organization. Executive pay is normally designed to incentivize executives to achieve company performance consistent with increases in shareholder value. Executive compensation is used in the structure of financial incentives and advantages to show the top management or top employee's gross income. As a consequence, a bulk of executive pay depends on performance unlike most staff; better still, if the business or executive do not perform up to expectations, the compensation may not be given. Executive compensation can be defined as all forms of financial and tangible services received by executives as part of an employment relationship which comprises of salary, bonuses, shares, call options, benefits, and perquisites. This is designed to take into consideration tax laws, the desires of the organisation and executives, government regulations. It serves as a reward for executives' performance (Greckhamer, 2011; Bebchuk et al., 2010; Maijoor \& Vanstraelen, 2006; Shin, Lee, \& Joo, 2009; Sun, Wei, \& Huamg, 2013).

However, if managers and the business perform well, they and the shareholders of the business will benefit much more from an outstanding performance. According to Akewushola and Saka (2018), the executive compensation scheme is a vital way of directing and influencing leadership team behaviour. As the structural model is uncertain, executive compensation is a significant problem in the corporate discussion as well as in practice (Otten, 2008), believed that financial payments and non-financial advantages given to management leadership as exchange for job done in support of an organization are executive compensation.

Typical kinds of staff compensated with executive compensation bundles comprise of vice presidents, corporate presidents, chief executive officers, managing directors, chief financial officers, and other senior executives. The inclusion of executive compensation agreements in executive reports helps the investors, equity holders, and other relevant stakeholders in making savvy resolutions financial will enable shareholders and other stakeholders to make savvy decisions on how the executive work to ensure their profit maximizations. Information on the 
configuration and nature of executive bonuses and stock option systems would decrease uncertainty and gain a competitive advantage for the business. Excellent disclosures would indicate transparency and boost executives ' standing (Simnett, Vanstraelen, \& Chua, 2009; Barakat et al., 2020). Therefore, transparency would involve various business advantages including reduced capital costs (Cao, Myers, Myers, \& Omer, 2015), greater worth and opportunities for managers.

Chaigneau (2018) claims that when the stock price best captures and represents the behavior and results of executives, the timing of executive compensation is strongly linked. The disclosure of helpful narrative and numerical data on manager remuneration would involve investors (Solomon \& Solomon, 2006). Disclosures must provide specific data on managerial decisions, assumptions, and estimates in order to be of high quality. Providing thorough disclosures would decrease the possibility of manipulating income or making short-sighted economic choices at the shareholders ' long-term cost. Furthermore, informational disclosures are essential for investors when assessing the importance of a company and future opportunities. Investors, financial analysts, and market authorities would highly value executive compensation disclosures to the level that they are substantial, relevant, and error-free (Throop, Stark, \& Rands, 1993). Lack of adequate executive pay information could result in significant political and agency costs.

\section{Financial Reporting Quality}

The Financial Accounting Standard Board (FASB) foremost goal of financial reporting is to deliver high-quality financial reporting data on economic institutions, mainly financially helpful for economic decision-making. The International Accounting Standard Board (IASB) in 2008 alluded to the importance of offering high-quality financial reporting data as it will have a positive impact on capital suppliers and other stakeholders in making the investment, credit, and comparable resource allocation choices that improve general market efficiency. "Financial Accounting Standards Board (FASB) Statement of Financial Accounting Concepts No. 1 (1978), which states that one objective of financial reporting is to inform present and potential investors in making rational investment decisions and in assessing the expected firm cash flows." Financial reporting quality was defined by Biddle, Hilary, and Verdi (2009) "as the precision with which financial reporting conveys information about the firm's operations, in particular, its expected cash flows, and that inform equity investors."

Bolo and Hassani (2007) alluded that financial reporting is an imperative significant output of an accounting system that attempts to equip consumers with the required data to make economic choices on the assessment of the profitability and results of an economic enterprise. Measuring and offering information that enables past performance to be evaluated, and efficiently assessing and predicting potential prospective benefits and expected activities can be regarded as a requirement for attaining this objective. Studies in the past show that financial reporting quality has been viewed as earnings quality, this is not so as earnings quality is defined according to Krishnan and Parsons (2008) as the aim of adequately evaluating the financial performance of a company and the degree to which the reported income capture economic reality.

The quality of financial reporting is a wider notion, referring not merely to financial data but also to disclosures and further helpful non-financial data for decision-making in the report (Beest, Braam, \& Boelens, 2009). Bushman and Smith (2001) are of the opinion that productivity, investment, and value-added of firms can be positively affected by financial accounting information. Hence, financial reporting quality helps in the reduction of liquidity risk, information 
risk and information symmetry among investors (Habib, Ranasinghe, \& Huang, 2018). Financial reporting quality can help in examining investment decisions made by the management and also support business control mechanisms. The quality of financial reporting governs the importance of accounting reporting and depends on it. High-quality financial reporting is crucial to impact consumers in making precise investment choices and also to increase the efficacy of the financial market (Herath \& Albarqi, 2017). The greater the quality of financial reporting, the greater the advantages to be obtained from financial reporting by investors and customers.

\section{Proxies for Measuring Financial Reporting Quality}

The measurement of financial reporting quality has been a subject to several academic scholars and there are numerous proxies accepted for determining it. The quality of financial reporting is a wide notion that not only refers to financial data but also involves other non-financial data that is helpful for decision making. It is germane to consider the population being studied before applying a proxy in measuring financial reporting quality. A suitable method of measuring financial reporting quality in the deposit money banks is the use of discretionary loan loss provisions as a proxy for earnings management and subsequently, measure of financial reporting quality. This model has been used by several empirical research studies (Othman \& Mersni, 2014; Kanagaretnam, Lobo, \& Mathieu, 2004, Chen, Warfield, \& Ye, 2011) and is now been embraced by numerous research study in this industry. The model is shown below:

$$
L l p_{i t}=\beta_{0}+\beta_{1} N p l_{i t}-1 \beta_{2} \Delta N p l_{i t}+\beta_{3} \Delta T l_{i t}+\varepsilon_{i t}
$$

Where $L l p=$ Total loan loss provision divided by loan at the beginning year $N p l=$ Non-performing loan at the opening year divided by loan at the beginning of the year $\Delta N p l=$ Change in non-performing loan divided by loan at the beginning of the year $\Delta T l_{i t}=$ Change in total loan divided by loan at the beginning of the year.

$\varepsilon_{i t}=$ The residual term, this functions as the discretionary Llp in estimating the earnings management. The error term which functions as proxy for accrual earnings management is multiplied by -1.Hence, higher values indicate higher financial reporting quality.

\section{Theoretical Review}

\section{Marginal Productivity Theory}

This theory has its background in micro and macro-economics and it is principally bothered with forecasting the pay levels of executives, (Roberts, 1956). The philosophers of Marginal Productivity Theory are of the view that the executive's median productivity be favorably associated with salaries instead of each employee receiving exactly their dessert. This indicates that executive compensation will be governed by productivity. Compensation will increase with higher productivity and vice-versa. Many of its executive compensation suggestions are produced in the context of evaluating the capacity of the company to produce earnings and maximize productive performance. The two key deductions on the executive compensation magnitude are derived from the theory of marginal productivity. First, the executive pay package size represents the net earnings of the company. In an organization where the entrepreneur is the sole owner and 
acts as the chief executive, the entrepreneur wants to attain the maximum return on his investments and this will happen when the marginal production cost is equivalent to the product market price.

The company boosts its earnings at this stage and the director maximizes its compensation equal to the company's revenues. In reality, such mere circumstances do not exist. Entrepreneurs generally acquire capital from external investors and decisions need to be made as to which share of earnings is given to who. This philosophy is not a framework to define profit distribution between an executive and others investing their cash. Second, the executive pay package size is proportionate to the marginal income product of the executive. The executive is presumed to be employed by the company and to be paid in accordance with its financial input. The quantity of compensation is the marginal net income product of the executive. The practical implication of the theory of marginal productivity is that mutually the profitability of the firm and the comparative financial contribution of the executive are determinants of the pay-level. The theory to some extent explains the star system created in the recruitment of certain executives. Executives whose leadership abilities have proven trail chronicles of generating shareholder value. Such people may request and receive excessive amounts of compensation compared to others doing the same work due to their ability to impact the future profitability and value of a company.

\section{METHODOLOGY}

The research design is a framework for the analysis and collection of data. This research employed a longitudinal research design to gather and analyze data on the evaluation of executive compensation and financial reporting quality in the quoted financial service industry in Nigeria. The population of the study comprised of the twenty-two deposit money banks in the financial services industry listed on the floor of the Nigerian Stock Exchange as of December 31, 2018. The determination of the sample size of this research study was purposefully done in essence purposive sampling method was adopted for this study. Hence fourteen (14) deposit money banks listed on the floor of the Nigerian Stock Exchange (NSE) was selected for this study.

Table 1. List of Deposit Money Banks in Nigeria

\begin{tabular}{|l|l|}
\hline S/N & NAME OF INSTITUTION \\
\hline 1 & ACCESS BANK PLC \\
\hline 2 & DIAMOND BANK PLC \\
\hline 3 & FIDELITY BANK PLC \\
\hline 4 & FIRST CITY MONUMENT BANK \\
\hline 5 & FIRST BANK NIGERIA LIMITED \\
\hline 6 & GUARANTY TRUST BANK PLC \\
\hline 7 & POLARIS BANK PLC \\
\hline 8 & UNION BANK OF NIGERIA PLC \\
\hline 9 & UNITED BANK OF AFRICA PLC \\
\hline 10 & ZENITH BANK PLC \\
\hline 11 & CITIBANK NIGERIA LIMITED \\
\hline 12 & ECOBANK NIGERIA PLC \\
\hline 13 & HERITAGE BANK LIMITED \\
\hline 14 & KEYSTONE BANK LIMITED \\
\hline 15 & STANBIC IBTC BANK PLC \\
\hline 16 & STANDARD CHARTERED BANK LIMITED \\
\hline
\end{tabular}




\begin{tabular}{|l|l|}
\hline 17 & STERLING BANK PLC \\
\hline 18 & UNITY BANK PLC \\
\hline 19 & WEMA BANK PLC \\
\hline 20 & SUNTRUST BANK NIGERIA LIMITED \\
\hline 21 & PROVIDUSBANK PLC \\
\hline 22 & JAIZ BANK PLC \\
\hline
\end{tabular}

Source: Researcher's compilation, 2019

Table 2. List of Sample Size

\begin{tabular}{|c|c|c|c|c|}
\hline & Company & Sector & Date Listed & Date of Incorporation \\
\hline 1 & Access Bank Plc. & $\begin{array}{l}\text { Financial } \\
\text { Services }\end{array}$ & $\begin{array}{l}\text { November } \\
18 \text { th } 1998 \\
\end{array}$ & February 8th 1989 \\
\hline 2 & First Bank Nigeria Limited & $\begin{array}{l}\text { Financial } \\
\text { Services }\end{array}$ & & \\
\hline 3 & $\begin{array}{l}\text { Eco bank Transnational } \\
\text { Incorporated }\end{array}$ & $\begin{array}{l}\text { Financial } \\
\text { Services }\end{array}$ & $\begin{array}{l}\text { September } \\
\text { 11th } 2006\end{array}$ & October 3rd 1985 \\
\hline 4 & Fidelity Bank Plc & $\begin{array}{l}\text { Financial } \\
\text { Services }\end{array}$ & $\begin{array}{l}\text { May 17th } \\
2005\end{array}$ & November 19th 1987 \\
\hline 5 & Guaranty Trust Bank Plc. & $\begin{array}{l}\text { Financial } \\
\text { Services }\end{array}$ & $\begin{array}{l}\text { September } \\
\text { 9th } 1996\end{array}$ & July 20th 1990 \\
\hline 6 & Sterling Bank Plc. & $\begin{array}{l}\text { Financial } \\
\text { Services }\end{array}$ & $\begin{array}{l}\text { August } \\
\text { 17th } 1993\end{array}$ & November 25th 1960 \\
\hline 7 & Union Bank Nig. Plc. [Bmf] & $\begin{array}{l}\text { Financial } \\
\text { Services }\end{array}$ & Invalid date & Invalid date \\
\hline 8 & United Bank For Africa Plc & $\begin{array}{l}\text { Financial } \\
\text { Services }\end{array}$ & $\begin{array}{l}\text { March 31st } \\
1970\end{array}$ & February 23rd 1961 \\
\hline 9 & Unity Bank Plc & $\begin{array}{l}\text { Financial } \\
\text { Services }\end{array}$ & $\begin{array}{l}\text { December } \\
\text { 22nd } 2005\end{array}$ & April 27th 1987 \\
\hline 10 & Wema Bank Plc. & $\begin{array}{l}\text { Financial } \\
\text { Services }\end{array}$ & $\begin{array}{l}\text { February } \\
\text { 13th } 1991\end{array}$ & May 2nd 1945 \\
\hline 11 & Zenith Bank Plc & $\begin{array}{l}\text { Financial } \\
\text { Services }\end{array}$ & $\begin{array}{l}\text { October } \\
21 \text { st } 2004\end{array}$ & May 30th 1990 \\
\hline 12 & Diamond Bank Plc & $\begin{array}{l}\text { Financial } \\
\text { Services }\end{array}$ & $\begin{array}{l}\text { May 27th } \\
2005\end{array}$ & December 20th 1990 \\
\hline 13 & First City Monument Bank & $\begin{array}{l}\text { Financial } \\
\text { Services }\end{array}$ & $\begin{array}{l}\text { June 21st } \\
2013\end{array}$ & November 20th 2012 \\
\hline 14 & Polaris Bank Plc & $\begin{array}{l}\text { Financial } \\
\text { Services }\end{array}$ & $\begin{array}{l}\text { November } \\
24^{\text {th }} 2005\end{array}$ & December $8^{\text {th }} 1989$ \\
\hline
\end{tabular}

Source: Researcher's compilation, 2019

Basically, in carrying out this research study, secondary sources were applied as it is suitable for the nature and purpose of this research. Secondary data is also extremely reliable because these data have been formerly collected out by various reputable organizations and world bodies. It has also been subjected to rules, principles, and regulations of respected professional 
bodies. This was sourced from the audited annual reports of the selected quoted financial service industry listed in the financial service industry quoted on the floor of the Nigerian Stock Exchange. The research work will cover a period of twelve (12) years from 2006 to 2017.

\section{Measurement of Dependent and Independent and Control Variables \\ Model for the Effect of Executive Compensation and Financial Reporting Quality}

To achieve this objective the study adopted models in previous research studies in line with Ke et al. (1999); Dechow et al. (1995); Chen (2010). The study functionally represents executive compensation as:

Excomp $=f(F P, S T, E B, T D C)$ .equation one

Where

\section{Excomp $=$ Executive Compensation}

$F P=$ Fixed pay

$S T=$ Short term cash bonus

$E B=$ Equity based pay

$T D C=$ Total direct compensation

The financial reporting quality was proxied with the level of earnings management and as such measured, using accrual models. The specific accrual model used was the Modified jones model. Financial reporting quality is functionally represented as:

$F R Q_{i t}=\beta_{0}+\beta_{1} N p l_{i t}-1 \beta_{2} \Delta N p l_{i t}+\beta_{3} \Delta T l_{i t}+\varepsilon_{i t} \ldots \ldots$.equation two

The variables are defined below in Table 3.6 below.

Table 3. Effect of executive compensation on financial reporting quality

\begin{tabular}{|c|l|l|}
\hline VARIABLES & $\begin{array}{l}\text { DESCRIPTION } \\
\text { MEASUREMENT }\end{array}$ & SOURCES \\
\hline ExComp & $\begin{array}{l}\text { A measure of compensation, } \\
\text { including the natural log of } \\
\text { fixed pay, natural log of a short } \\
\text { term cash bonus, natural log of } \\
\text { equity-based pay, natural log of } \\
\text { total direct compensation. }\end{array}$ & $\begin{array}{l}\text { Sun, Wei, and Huang (2013), Iatridis } \\
\text { (2018), Basu et al. (2007) }\end{array}$ \\
\hline$F P$ & Natural log of fixed pay & $\begin{array}{l}\text { Sun, Wei, and Huang (2013), Iatridis } \\
\text { (2018), Basu et al. (2007) }\end{array}$ \\
\hline$S T$ & $\begin{array}{l}\text { Natural log of short term cash } \\
\text { bonus }\end{array}$ & $\begin{array}{l}\text { Sun, Wei, and Huang (2013), Iatridis } \\
\text { (2018), Basu et al. (2007) }\end{array}$ \\
\hline$E B$ & Natural log of equity based pay & $\begin{array}{l}\text { Sun, Wei, and Huang (2013), Iatridis } \\
\text { (2018), Basu et al. (2007) }\end{array}$ \\
\hline
\end{tabular}




\begin{tabular}{|c|c|c|}
\hline$T D C$ & $\begin{array}{l}\text { Natural log of total direct } \\
\text { compensation }\end{array}$ & $\begin{array}{l}\text { Sun, Wei, and Huang (2013), Iatridis } \\
\text { (2018), Basu et al. (2007) }\end{array}$ \\
\hline$F R Q_{\text {it }}$ & $\begin{array}{l}\text { The indicator of earning } \\
\text { management }\end{array}$ & $\begin{array}{l}\text { Monah and Okojie (2018), } \\
\text { Cheng, Warfield, and Ye (2011) }\end{array}$ \\
\hline$L l p$ & $\begin{array}{l}\text { Total loan loss provision } \\
\text { divided by loan at the } \\
\text { beginning year }\end{array}$ & $\begin{array}{l}\text { Monah and Okojie (2018), } \\
\text { Cheng, Warfield, and Ye (2011) }\end{array}$ \\
\hline$N p l$ & $\begin{array}{l}\text { Non-performing loan at the } \\
\text { opening year divided by loan } \\
\text { at the beginning of the year }\end{array}$ & $\begin{array}{l}\text { Othman and Mersni (2014), Zoubi and Al- } \\
\text { Khazali (2007), Cheng, Warfield, and Ye } \\
\text { (2011) }\end{array}$ \\
\hline$\Delta N p l$ & $\begin{array}{l}\text { Change in non-performing } \\
\text { loan divided by loan at the } \\
\text { beginning of the year }\end{array}$ & $\begin{array}{l}\text { Kanagaretnam, Lobo, and Mathieu } \\
\text { (2004), Monah and Okojie (2018) }\end{array}$ \\
\hline$\Delta T l_{i t}$ & $\begin{array}{l}\text { Change in total loan divided by } \\
\text { loan at the beginning of the } \\
\text { year. }\end{array}$ & $\begin{array}{l}\text { Othman and Mersni (2014), Zoubi and Al- } \\
\text { Khazali (2007), Cheng, Warfield, and Ye } \\
\text { (2011), }\end{array}$ \\
\hline$\varepsilon_{i t}$ & The residual term & $\begin{array}{l}\text { Othman and Mersni(2014), Zoubi and Al- } \\
\text { Khazali (2007), Cheng, Warfield, and Ye } \\
\text { (2011) }\end{array}$ \\
\hline$F R Q_{i t}$ & $\begin{array}{l}\text { The indicator of earning } \\
\text { management }\end{array}$ & $\begin{array}{l}\text { Monah and Okojie(2018), } \\
\text { Cheng, Warfield, and Ye (2011) }\end{array}$ \\
\hline
\end{tabular}

Source: Researchers' compilation (2019)

The objectives of this research work was achieved using descriptive and inferential statistics in the presentation and analysis of data. Descriptive such as mean, median, minimum and maximum values, standard deviation, tabulation, graphs, and percentages will be used to analyze the data. Furthermore, inferential statistical techniques was applied with the aid of STATA 16.This is a complete, integrated statistical software package that provides everything you need for data analysis, data management, and graphics. Diagnostics tests was conducted to know the fitness and appropriateness of the data before further analysis. The inferential statistics used in this study includes multiple regression analysis, robust regression and pairwise correlation.

\section{Hypothesis}

$H_{01}$ : Executive compensation has no significant effect on financial reporting quality in the quoted financial service industry in Nigeria?

\section{Testing for Heteroskedasticity and Multicollinearity}

Effect of Executive Compensation on Financial Reporting Quality in the Quoted Financial Service Industry in Nigeria. 
Table 4. Model Diagnostic Tests

\begin{tabular}{|c|c|c|}
\hline Regression Assumptions: & Test: & Ideal \\
\hline 1. Heterokedasticity Problem & $\begin{array}{ll}\text { Breusch-Pagan Test: } \\
\text { Chi2(1) } & : 52.71 \\
\text { p-value } & : 0.000\end{array}$ & $\begin{array}{l}> \\
0.05\end{array}$ \\
\hline 2. Multicollinearity Problem & $\begin{array}{ll}\text { Variance Inflation Factor: } & \\
\text { lnexcomp: } & 1.14 \\
\text { lncs: } & 1.09 \\
\text { boardsize : } & 1.09 \\
\text { roa: } & 1.09 \\
\text { lev: } & 1.07 \\
\text { lnfa: } & 1.03\end{array}$ & $<5.00$ \\
\hline $\begin{array}{l}\text { 3. Residuals are not normally } \\
\text { distributed }\end{array}$ & $\begin{array}{lr}\text { Shapiro-Wilk W Normality Test } \\
\text { z: } & 9.388 \\
\text { p-value: } & 0.000 \\
\end{array}$ & $>0.01$ \\
\hline 4. No Omitted Variable Bias & $\begin{array}{ll}\text { Linktest: } & \\
\text { t: } & 2.279 \\
\text { p-value: } & 0.024 \\
\end{array}$ & $>0.05$ \\
\hline 5. Functional Form Problem & $\begin{array}{lc}\text { Test for Appropriate functional form: } \\
\mathrm{F}(3,133): & 1.908 \\
\text { Prob: } & 0.003\end{array}$ & $>0.05$ \\
\hline 6. Influential Observations & $\begin{array}{l}\text { Cook's Distance: } \\
\text { No distance is above the cut-off value }\end{array}$ & $<1$ \\
\hline
\end{tabular}

Source: Authors' Compilation (2019)

\section{Diagnostic Tests}

Table 4 presents the several diagnostic tests of the variables. We checked for heterokedasticity, multicollinearity, normality, omitted variable bias, functional form and influential observations tests. Heterokedasticity test were conducted using Breusch-pagan hettest method. The results (Chi2 $(1)=52.71$, p-value $=0.000)$ showed the absence of heterokedasticity and as such the data is homokedastic. Multicollinearity Test was conducted using variance inflation factor (VIF). The results showed no incidence of multicollinearity. This is because all the variables had VIF less than five. Normality Test was also conducted using Shapiro Wilk W test and the result (z: 9.388, p-value: 0.000) indicates that the results are non-normal. Omitted Variable bias test was also conducted using Link test and the result (t: 2.279, p-value: 0.024) shows that there is no problem of omitted variable bias. Outlier test was conducted using standardized residuals, studentised residuals, leverage and cook's distance.

The result $(<1)$ showed the presence of outliers which may influence the outcome of the result. The study therefore, employed robust regression in the analyses of the data. Robust regression is ideally suited for this kind of data because due to the existence of outliers in the set of data may skew the classical minimum square method to calculate and result to inconsistent findings (Verardi \& Croux, 2009; Yu et al., 2019). 
EMPIRICAL RESULT

Table 5. Descriptive Statistics of Variables

\begin{tabular}{|l|l|l|l|l|l|l|}
\hline Variables & Number & Mean & Std.Dev. & Min & Med & Max \\
\hline & & & & & & \\
\hline Frq & 168 & $-9.09 \mathrm{e}-08$ & 32.618 & -35.853 & -5.414 & 311.528 \\
\hline Lnexcomp & 168 & 12.237 & 1.280 & 7.925 & 12.330 & 15.922 \\
\hline Lnfa & 168 & 3.341 & 0.653 & 0 & 3.332 & 4.278 \\
\hline Lncs & 168 & 19.589 & 1.918 & 12.404 & 20.039 & 21.869 \\
\hline boardsize & 168 & 14.309 & 2.464 & 7 & 14 & 21 \\
\hline Roa & 168 & 0.274 & 1.743 & -2.039 & 0.048 & 21.588 \\
\hline Lev & 168 & 0.771 & 0.666 & -6.972 & 0.855 & 2.550 \\
\hline
\end{tabular}

Source: Authors' Compilation (2019)

The table showed the descriptive statistics of the variables in equation 3.9. Where frq represents financial reporting quality, lnexcomp represents natural logarithm of executive compensation, Infa represents the firms age, lncs stands for natural logarithm of customers deposit, board size represents the banks board size, ROA measured return on assets, and lev measured the leverage.

Table 4.5 presents essentially the descriptive statistics of dependent and the explanatory variables in the study for the period under consideration (2006-2017). The dependent variable frq and the explanatory variables included frq, lnexcomp, Infa, lncs, boardsize, roa and lev. The total number of observation was 168 , for 14 banks .The descriptive statistics included mean,median, standard deviation, minimum and maximum values of all the variables. The result showed a high level of consistency from the data as indicated by their mean and median falling within normal range of the maximum and minimum value of the panel data. The mean and median of lnexcomp $\mathrm{N} 12,237,000$ and N12,330,000 respectively with a standard deviation of 1.28. The average age of the the firm $(\operatorname{lnfa})$ from the data is 3yrs. The mean of lncs showed N19,589,000,000 while the maximum was $\mathrm{N} 21,869,000,000$.

The difference in the median value and the mean showed N2,280,000,000 which is expected. The average number of board size was 14 while the maximum was 21 , which is above the maximum required board size of 20.The result of the table showed the mean of roa to be 0.274 , this indicated that average return on assets by the banks is $27.4 \%$, while the maximum return on assets is $210 \%$. This is abnormally high and the implication for the economy is that the bank are making supernormal profits by charging excess interest from the customers. This also indicated the involvement of banks in illegal transactions which may include round tripping i.e foreign exchange fraud etc. The mean of lev showed 0.771, this indicated that the banks are highly geared at $77 \%$, and as such will suffer debt related problems.

Table 6. Pairwise Correlation Analysis

\begin{tabular}{|l|l|l|l|l|l|l|l|}
\hline Variables & Frq & Lnexcomp & Lnfa & Lncs & Boardsize & Roa & Lev \\
\hline Frq & 1.000 & & & & & & \\
\hline lnexcomp & -0.000 & 1.000 & & & & & \\
\hline Lnfa & -0.044 & -0.104 & 1.000 & & & & \\
\hline Lncs & -0.394 & $0.248^{*}$ & -0.003 & 1.000 & & & \\
\hline
\end{tabular}




\begin{tabular}{|l|l|l|l|l|l|l|l|}
\hline Boardsize & 0.014 & $0.276^{*}$ & -0.009 & $0.195^{*}$ & 1.000 & & \\
\hline Roa & -0.010 & 0.129 & 0.081 & 0.094 & -0.006 & 1.000 & \\
\hline Lev & 0.021 & -0.043 & 0.0058 & -0.038 & 0.087 & $-0.219^{*}$ & 1.000 \\
\hline \multicolumn{7}{|c|}{ Source: Authors' Compilation (2019) }
\end{tabular}

The table showed the correlational matrix of the variables in equation 3.9. Where frq represents financial reporting quality, lnexcomp represents natural logarithm of executive compensation, Infa represents the firms age, lncs stands for natural logarithm of customers deposit, boardsize represents the banks boardsize,,roa measured return on assets, and lev measured the leverage.

Table 6 presents the correlation matrix of the variables and the result showed that the correlation between financial reporting quality and the independent variables (frq, lnexcomp, Infa, lncs, boardsize and roa) are low. The table also shows that slight correlation exist between lnexcomp and lncs and boardsize but it is not significant.

Table 7. Robust Regression results

\begin{tabular}{|l|l|l|l|l|l|l|}
\hline Frq & Coef. & $\begin{array}{l}\text { Robust } \\
\text { Std.Err. }\end{array}$ & $\mathrm{z}$ & $\mathrm{P}>/ \mathrm{l} \mathrm{z} \mathrm{l}$ & {$[95 \%$ Conf. } & Interval] \\
\hline lnexcomp & -0.139 & 0.048 & -2.89 & 0.004 & -0.235 & -0.440 \\
\hline Lnfa & 0.017 & 0.096 & 0.18 & 0.858 & -0.173 & 0.207 \\
\hline Lncs & -0.029 & 0.299 & -1.00 & 0.319 & -0.089 & 0.029 \\
\hline boardsize & 0.009 & 0.024 & 0.40 & 0.688 & -0.038 & 0.058 \\
\hline roa & 0.318 & 0.032 & 9.95 & 0.000 & 0.254 & 0.381 \\
lev & 0.083 & 0.847 & 0.98 & 0.327 & -0.084 & 0.251 \\
\hline _cons & -3.523 & 0.837 & -4.21 & 0.000 & -5.179 & -1.867 \\
\hline
\end{tabular}

Source: Authors' Compilation (2019)

The table showed the robust regression result of the variables in equation 3.9. Where frq represents financial reporting quality, lnexcomp represents natural logarithm of executive compensation, Infa represents the firms age, lncs stands for natural logarithm of customers deposit, boardsize represents the banks boardsize, roa measured return on assets, and lev measured the leverage.

\section{DISCUSSION OF FINDINGS}

Table 7 summarizes the robust regression analyses of executive compensation and financial reporting quality of 14 banks between 2006-2017. The F Stat result (prob > F =0.0000) shows that the data fits the model. The table showed that only two variables were significant, and these two variables have effect on frq. The significant variables are excomp with a regression coefficient of -0.139 ( $\mathrm{p}$-value 0.004 ), this indicated that excomp tends to reduce frq by $13.9 \%$. Therefore, hypothesis $\mathrm{H}_{02}$ is rejected. This result validates the results of the works of Safari, Cooper, and Dellaporta, 2016; Efendi et al., 2007; Bergstresser and Philippon, 2006; and Cheng and Warfield (2005) conducted in various countries, but negated Armstrong et al., 2010; Warfield et al., 1995. This results mitigates the agency problem in the agency theory. The implication of the result is that the executives' director will strive to maximize their compensation, which will result in 
earnings management, income smoothing, which in the long run lead to a reduction in the quality of their financial reporting.

The coefficient of roa with the results (coef. $=0.317, \mathrm{p}=0.000$ ) showed a positive significant relationship with $\mathrm{frq}$, at $5 \%$ level of significance. This indicated that roa tends to increase frq by $31.7 \%$. This is in consistency with the works of He,2014; Dechow et al., 1995. This implies that abnormal accruals are positively related to earnings performance. This results further corroborates the marginal productivity theory which indicates that the maximum return on his investments and this will happen when the marginal production cost is equivalent to the product market price. The company boosts its earnings at this stage and the director maximizes its compensation and at this point its financial reporting quality will attain a higher level as indicated by a positive significant relationship.

\section{SUMMARY AND CONCLUSION}

Assessment of the effect of executive compensation on financial reporting quality was also conducted by pre-estimation test of descriptive statistics, correlation and regression analysis. The result of the pairwise association of the variables employed in achieving the objective also showed that the existence of multicollinearity problem is low as all pairwise association of the interest variables is less than the threshold of 0.8 . The robust regression analysis which was employed due to the presence of outliers revealed a negative significant relationship exists between executive compensation and financial reporting quality, and a positive significant relationship between return on assets and financial reporting quality, hence we reject the null hypothesis $\left(\mathrm{H}_{01}\right)$.

In conclusion the compensation payment made to the executive have an inverse effect on financial reporting quality. The bank usually engage in earnings management, income smoothing and this is reflected in the reaction of the executive compensation to the financial reporting quality. This was manipulated in the period under consideration.

\section{REFERENCES}

Adegbie, F.F., \& Fofah, E.T. (2016). Ethics, Corporate Governance and Financial Reporting in the Nigerian Banking Industry: Global Role of International Financial Reporting Standards. Accounting and Finance Research, 5(1), 50-63.

Akewushola, R.O., \& Saka, R.O. (2018). Executive Compensation and Organizational Financial Performances: Evidence from Selected Diversified Firms in Nigeria. Journal of Business and Management, 20(3), 08-17.

Amiram, D., Bozanic, Z., Cox, J. D., Dupont, Q., Karpoff, J. M., \& Sloan, R. (2018). Financial reporting fraud and other forms of misconduct: a multidisciplinary review of the literature. Review of Accounting Studies, 23(2), 732-783.

Akgün, A. İ. (2016). The Reliability of Financial Reporting within Corporate Governance: Evidence from Turkey. Journal of Accounting \& Finance, 71, 179-199.

Armstrong, C., Guay, W., \& Weber, J. (2010). The role of information and financial reporting in corporate governance and debt contracting. Journal of Accounting and Economics, 50 (2-3), 179-234 
Bebchuk, L., Grinstein, Y., \& Peyer, U. (2010). Lucky CEOs and lucky directors. Journal of Finance, 65(6), 2363-2401.

Beest, F.V, Braam, G., \& Boelens, S. (2009). Quality of Financial Reporting: measuring qualitative characteristics. Nijmegen Center for Economics (NiCE) Institute for Management Research Radboud University Nijmegen.

Bergstresser, D., \& Philippon, T. (2006). CEO incentives and earnings management. Journal of Financial Economics 80(3), 511-529.

Biddle, G. C., Hilary, G., \& Verdi, R. S. (2009). How does financial reporting quality relate to investment efficiency? Journal of Accounting and Economics, 48, 112-131.

Bolo, G. \& Hassani, S. A. (2007). Earnings management and its measurement: A theoretical approach. Iranian Association of Certified Public Accountants, 4(12), 72-88.

Bushman, R. M., \& Smith, A. J. (2001). Financial accounting information and corporate governance. Journal of accounting and Economics, 32(1-3), 237-333.

Basu, S., Hwang, L. S., Mitsudome, T., \& Weintrop, J. (2007). Corporate governance, top executive compensation and firm performance in Japan. Pacific-Basin Finance Journal, 15(1), 56-79.

Barakat, F. S. Q., Perez, M. V. L., Ariza, L. R., Barghouthi, O. A., \& Islam, K. M. A. (2020). The impact corporate governance on internet financial reporting: empirical evidence from palestine. International Journal of Accounting \& Finance Review, 5(4), 1-22. https://doi.org/10.46281/ijafr.v5i4.852

Cao, Y., Myers, J. N., Myers, L. A., \& Omer, T. C. (2015). Company reputation and the cost of equity capital. Review of Accounting Studies, 20(1), 42-81.

Chaigneau, P. (2018). The optimal timing of CEO compensation. Finance Research Letters, 24, 90-94.

Chen, T. (2010). Analysis on accrual-based models in detecting earnings management. Lingnan Journal of Banking, Finance and Economics, 2(5), 58-65.

Carpenter, T. D., \& Reimers, J. L. (2005). Unethical and fraudulent financial reporting: Applying the theory of planned behavior. Journal of Business Ethics, 60(2), 115-129.

Cheng, Q., Warfield, T., \& Ye, M. (2011). Equity incentives and earnings management: evidence from the banking industry. Journal of Accounting, Auditing \& Finance, 26(2), 317-349.

Darweesh, M. S. (2015). Correlations between corporate governance, financial performance, and market value. 
Dechow, P. M, Sloan, R. G., \& Sweeney, A. P. (1995). Detecting Earnings Management. The Accounting Review, 70(2), 193-225.

Dimitrova, J., Gorgieva-Trajkovska, O., Koleva, B., NACHKOVA, A., \& Dimitrova, E. (2016). Corporate governance and financial reporting in macedonia through the prism of independent auditors reports. Economic Development/Ekonomiski Razvoj, 18(3).

Devers, C. E., Cannella Jr, A. A., Reilly, G. P., \& Yoder, M. E. (2007). Executive compensation: A multidisciplinary review of recent developments. Journal of management, 33(6), 10161072.

Efendi, J., Srivastava, A., \& Swanson, E. P. (2007). Why do corporate managers misstate financial statements? The role of option compensation and other factors. Journal of financial economics, 85(3), 667-708.

Financial Accounting Standards Board. (1978). Objectives of financial reporting by business enterprises (No. 1). Financial Accounting Standards Board.

Gomez-Mejia, L. R., \& Balkin, D. B. (1992).Compensation organizational strategy and firm performance. Cincinnati: South-Western. Publication. $1^{\text {st }}$ Edition

Goodwin, J., \& Seow, J. L. (2002). The influence of corporate governance mechanisms on the quality of financial reporting and auditing: Perceptions of auditors and directors in Singapore. Accounting \& Finance, 42(3), 195-223.

Greckhamer, T. (2011). Cross-cultural differences in compensation level and inequality across occupations: A set-theoretic analysis. Organization Studies, 32(1), 85-115.

Habib, A., \& Jiang, H. (2015). Corporate governance and financial reporting quality in China: A survey of recent evidence. Journal of International Accounting, Auditing and Taxation, 24, 29-45.

Herath, S. K., \& Albarqi, N. (2017). Financial reporting quality: A literature review. International Journal of Business Management and Commerce, 2(2), 1-14.

Hong, B., Li, Z., \& Minor, D. (2016). Corporate governance and executive compensation for corporate social responsibility. Journal of Business Ethics, 136(1), 199-213.

Habib, A., Ranasinghe, D., \& Huang, H. J. (2018). A literature survey of financial reporting in private firms. Research in Accounting Regulation, 30(1), 31-37.

Iatridis, G. E. (2018). Accounting Discretion and Executive Cash Compensation; An Empirical Investigation of Corporate Governance, Credit Ratings and Firm Value. Journal of International Financial Markets, Institutions \& Money, 1, 23-39. 
IASB. (2008). Exposure Draft on an improved Conceptual Framework for Financial Reporting: The Objective of Financial Reporting and Qualitative Characteristics of Decision-useful Financial Reporting Information. London.

Kalyani, S., Mathur, N., \& Gupta, P. (2019). Does corporate governance affect the financial performance and quality of financial reporting of companies? A study on selected Indian companies. In Business Governance and Society (pp. 105-125). Palgrave Macmillan, Cham.

Kanagaretnam, K., Lobo, G. J., \& Mathieu, R. (2004). Earnings management to reduce earnings variability: evidence from bank loan loss provisions. Review of Accounting and Finance, 3(1), 128-148.

Ke, B., Petroni, K., \& Safieddine, A. (1999). Ownership concentration and sensitivity of executive pay to accounting performance measures: Evidence from publicly and privately-held insurance companies. Journal of Accounting and Economics, 28(2), 185-209.

Krishnan, G. \& Parsons, L. (2008). Getting to the Bottom Line: An Exploration of Gender and Earnings Quality. Journal of Business Ethics, 78(1), 65-76.

Maijoor, S. J., \& Vanstraelen, A. (2006). Earnings management within Europe: the effects of member state audit environment, audit firm quality and international capital markets. Accounting and business research, 36(1), 33-52.

Mohammadi, S. M. (2014). The relationship between financial reporting quality and investment efficiency in Tehran stock exchange. International Journal of Academic Research in Business and Social Sciences, 4(6), 104-113.

Monah, A., \& Okojie, O. (2018). The Effects of International Financial Reporting Standards Adoption on Earnings Management: Evidence from Commercial Banks in Liberia.

Nerantzidis, M., (2018). Enhancing financial reporting: challenges and opportunities in corporate governance statements, Corporate Governance: The International Journal of Business in Society, 18(5), 773-778.

Othman, H. B., \& Mersni, H. (2014). The use of discretionary loan loss provisions by Islamic banks and conventional banks in the Middle East region: A comparative study. Studies in Economics and Finance, 31(1), 106-128

Oba, V. C. (2014). Board Dynamics and Financial Reporting Quality in Nigeria. Review of International Comparative Management, 15(2), 226-236.

Ogbonna, G. N., \& Ebimobowei, A. (2012). Effect of ethical accounting standards on the quality of financial reports of banks in Nigeria. Current Research Journal of Social Sciences, 4(1), 69-78. 
Omoregie, O. K., \& Kelikume, I. (2017). Executive compensation and banking sector performance: evidence from Nigeria. The Journal of Developing Areas, 51(2), 1-15.

Otten, J. A. (2008). Theories on executive pay: A literature overview and critical assessment. Munich Personal RePEc Archive (MPRA).Retrieved from mpra.ub.unimuenchen.de/6969/ Accessed on 9/03/2019.

Rahman, K. M., \& Bremer, M. (2016). Effective Corporate Governance and Financial Reporting in Japan. Asian Academy of Management Journal of Accounting and Finance (AAMJAF), 12(1), 93-122.

Researcher's Compilation. (2019). Retrieved from http:/www.nse.com.ng/issuers/listedsecurities/listed-companies

Roberts, D. R. (1956). A general theory of executive compensation based on statistically tested propositions. The Quarterly Journal of Economics, 70(2), 270-294.

Safari, M., Cooper, B. J., \& Dellaportas, S. (2016). The influence of remuneration structures on financial reporting quality: Evidence from Australia. Australian Accounting Review, 26(1), 66-75.

Simnett, R., Vanstraelen, A., \& Chua, W. (2009).Assurance on Sustainability Reports: An International Comparison. The Accounting Review, 84(3), 937-967.

Shin, E. D., Lee, J., \& Joo, I. K. (2009). CEO compensation and US high tech and low-tech firm's corporate performance. Contemporary management research, 5(1), 93-106.

Solomon, J. \& Solomon, A. (2006). Private Social, Ethical and Environmental Disclosure. Accounting, Auditing \& Accountability Journal, 19(4), 564-591.

Sun, F., Wei, X., \& Huang, X. (2013). CEO compensation and firm performance: Evidence from the US property and liability insurance industry. Review of Accounting and Finance, $12(3), 252-267$.

Throop, G. M., Starik, M., \& Rands, G. P. (1993). Sustainable strategy in a greening world: Integrating the natural environment into strategic management. Advances in strategic management, 9, 63-92.

Verardi, V., \& Croux, C. (2009). Robust regression in Stata. The Stata Journal, 9(3), 439-453.

Warfield, T. D., Wild, J. J., \& Wild, K. L. (1995). Managerial ownership, accounting choices, and informativeness of earnings. Journal of accounting and economics, 20(1), 61-91.

Yu, D., Ding, C., He, N., Wang, R., Zhou, X., \& Shi, L. (2019). Robust estimation and confidence interval in meta-regression models. Computational Statistics \& Data Analysis, 129, $93-$ 118. 
Yiu, D. W., Wan, W. P., \& Xu, Y. (2019). Alternative governance and corporate financial fraud in transition economies: Evidence from China. Journal of Management, 45(7), 2685-2720.

Zadeh, F. N., Salehi, M., \& Shabestari, H. (2018). The relationship between corporate governance mechanisms and internet financial reporting in Iran. Corporate Governance: The International Journal of Business in Society, 18(1), 1-22.

Zoubi, T. A., \& Al-Khazali, O. (2007). Empirical testing of the loss provisions of banks in the GCC region. Managerial Finance, 33(7), 500.

\section{Copyrights}

Copyright for this article is retained by the author(s), with first publication rights granted to the journal. This is an open-access article distributed under the terms and conditions of the Creative Commons Attribution license (http://creativecommons.org/licenses/by/4.0). 